\title{
Mobil Ödeme Teknolojisi Kabulünün Teknoloji Kabul Modeli ile İncelenmesi: Ampirik Bir Araștırma ${ }^{1}$
}

\author{
Ceylan BOZPOLAT \\ Sorumlu Yazar, Nevşehir Hacı Bektaş Veli Üniversitesi, İ̈BF, \\ Bankacılık ve Finans Bölümü \\ cakdogan@nevsehir.edu.tr,ORCID:0000-0002-9672-8308
}

Hülya SEYHAN

Nevşehir Hacı Bektaş Veli Üniversitesi, Sosyal Bilimler Enstitüsü

hulyaseyhann0@gmail.com.tr, ORCID: 0000-0002-6632-9189

\begin{abstract}
Öz
Bu çalışma banka müşterilerinin mobil ödeme teknolojisini kabul etme süreçlerinde etkili olan faktörleri belirlemek amacıyla yapılmıştır. Bu bağlamda Davis (1989) tarafından geliştirilen Teknoloji Kabul Modeli (TAM) kullanılmıştır. Çalışmaya ilişkin verileri toplamak amacıyla Nevşehir ilinde kolay örnekleme metodu ile belirlenen 500 mobil ödeme kullanıcısına anket uygulanmıştır. Elde edilen veriler ile öncelikle Açıklayıcı ve Doğrulayıcı Faktör Analizi, sonrasında ise Path Analizi yapılmıştır. Açıklayıcı faktör analizi sonucunda TAM'ın alt değişkenlerini destekleyen faktörler ortaya çıkmıştır. Doğrulayıcı faktör analizinin uyum değerleri ise kabul edilebilir uyum göstermiştir. Path analizi sonucunda doğrudan etki bakımından algılanan kullanım kolaylığının algılanan fayda; algılanan faydanın tutum; tutumun ise niyet üzerinde pozitif yönde etkisi olduğu görülmüştür. Sonuçlar dolaylı etki bakımından incelendiğinde ise algılanan kullanım kolaylığının, tutumu ve niyeti şekillendiren en güçlü değişken olduğu tespit edilmiştir. Mobil ödeme teknolojisinin kabulünü öngörmek için TAM'ın sınandığı bu çalışma, literatüre katkı sağlamakta ve sonuçları çözüm sağlayıcılara faydalı bilgiler sunmaktadır.
\end{abstract}

Anahtar Kelimeler: Mobil Ödeme, Teknoloji Kabul Modeli, Path Analizi

Jel Sınıflandırma Kodları: M30, M31

\section{Investigation of Mobile Payment Technology Acceptance with Technology Acceptance Model: An} Empirical Research ${ }^{2}$

\section{Abstract}

This study was carried out to determine the factors that affect the process of accepting mobile payment technology of bank customers. In this context, the Technology Acceptance Model (TAM) developed by Davis (1989) was used. In order to collect the data related to the study, a questionnaire was applied to 500 mobile payment users determined by convenience sampling method in Nevsehir. Explanatory and Confirmatory Factor Analysis and then Path Analysis were performed with the obtained data. As a result of the explanatory factor analysis, emerged the factors that support the sub-variables of TAM. The agreement values of the confirmatory factor analysis showed acceptable agreement. As a result of path analysis, perceived usefulness of perceived ease of use in terms of direct effect; attitude of perceived usefulness; attitude has a positive effect on intention. When the results were examined in terms of indirect effect, perceived ease of use was found to be the most powerful variable shaping attitude and intention. This study, in which TAM is tested to predict the acceptance of mobile payment technology, contributes to the literature and the results provide useful information to solution providers. Keywords: Mobile Payment, Technology Acceptance Model, Path Analysis

JEL Classification Codes: M30, M31

\footnotetext{
${ }^{1}$ Bu çalışma, Dr. Öğr. Üyesi Ceylan BOZPOLAT danışmanlığında Nevşehir Hacı Bektaş Veli Üniversitesi Sosyal Bilimler Enstitüsünde yürütülen "İnovatif Bankacılık Ürünleri Kullanımının Teknoloji Kabul Modeli ile İncelenmesi” başlıklı yüksek lisans çalışmasından türetilmiştir.

${ }^{2}$ Extended abstract is presented at the end of the article.
}

Geliş Tarihi (Received): 13.09.2019 - Kabul Edilme Tarihi (Accepted): 26.04.2020

Atıfta bulunmak için/Cite this paper:

Bozpolat, C. ve Seyhan, H. (2020) Mobil ödeme teknolojisi kabulünün teknoloji kabul modeli ile incelenmesi: Ampirik bir araştırma. Çankırı Karatekin Üniversitesi İIBF Dergisi, 10 (1), 119-145. Doi: 10.18074/ckuiibfd.619852. 


\section{Giriş}

Mobil teknolojilerin hızla gelişmesiyle birlikte tüketici taleplerinde meydana gelen büyük değişiklikler diğer sektörlerde olduğu gibi bankacılık sektöründe de ürün ve hizmet yelpazesinin genişlemesine neden olmuştur. Teknolojinin gelişmesiyle birlikte bireyler ve kurumlar mobil cihazları (cep telefonu, tablet vs.) daha sık kullanmaya başlamışlar ve zamandan tasarruf etmek amacıyla bu cihazları bankacılık işlemlerini gerçekleştirme konusunda bir araç haline getirmişlerdir. $\mathrm{Bu}$ bağlamda banka işletmeleri elektronik ödeme yöntemlerine farklı boyutlar kazandırmak amacıyla mobil ödeme sistemini ortaya çıkarmış ve bireylerin/kurumların kullanımına arz etmişlerdir.

Mobil ödeme sistemi ilk kez 1997 yılında "Finlandiya Helsinki Havaalanı'ndaki Coca Cola" otomatlarında faaliyete (içecek ihtiyacı olan müşterilerin cep telefonlarından SMS göndererek) geçirilmiştir. Bankacılık alanında mobil ödeme, mobil bankacılık hizmeti kapsamında 1997 yılında " Finlandiyalı Merita Bank" tarafından SMS yoluyla kullanıma arz edilmiştir (Kutsal, 2018). Ülkemizde bankacılık sektöründe mobil ödeme sistemi ilk kez 2012 yılında Türki Algılanan Zevk ve Nesnel Kullanılabilirlik ve İş Bankası tarafından (QR Kod ödeme sistemi) hayata geçirilmiştir (İşbankası, 2012).

Mobil ödeme, kablosuz ve diğer iletişim teknolojilerinden yararlanarak mobil bir cihazla (cep/ ak1llı telefon, dijital asistan vb.) hizmet, mal ve fatura ödemelerini gerçekleştirmeye yarayan teknolojidir (Dahlberg, Mallat, Ondrus ve Zmijewsska, 2007, s. 1). Ürün ve hizmetler için alternatif bir ödeme yöntemi olan mobil ödeme, kullanıcılarına teknolojik hizmetlerin yanı sıra çeşitli ödeme (temassız, karekod, NFC) işlemleri de sunmaktadır (Dahlberg, Mallat, Ondrus ve Zmijewsska, 2006, s. 2). Bu sistemde ödemeler, bir mobil cihaz üzerinden, para veya fonların alıcıdan alıcıya bir aracı aracılığıyla ya da doğrudan (aracı olmadan) aktarılmasıyla gerçekleştirilmektedir (Mallat, 2007, s. 2). Mobil ödeme sistemi kullanımının bu denli basit olması ve bireyin/ kullanıcının hayatını zamansal açıdan kolaylaştırması bu sistem kullanıcılarının sürekli artmasına neden olmaktadır.

Günümüz itibariyle mobil ödeme sisteminin popüler hale gelmesi ve tüketiciler tarafindan kabulünün artması birçok yazar ve akademisyeni bu konu üzerine araştırma/çalışma yapmaya yönlendirmiştir (Zmijewska, Lawrence ve Steele, 2004; Ustasüleyman ve Eyüboğlu, 2010; Eyüboğlu ve Sevim, 2016; Eyüboğlu ve Sevim, 2017; Kalyoncuoğlu, 2018; Askool, Pan, Jacobs ve Tan, 2019; Özer, Poyraz ve Kızgın, 2019). Yapılan bu ulusal ve uluslararası nitelikteki çalışmaların (bkz. Tablo 1 ve 2) incelenmesiyle mobil ödeme sistemini tüketicinin kabul etmesinde kilit faktörlerin olduğu sonucuna ulaşılmıştır. Bu faktörler üzerine yapılacak olan mevcut çalışma mobil ödeme sistemin nasıl aktif bir şekilde pazarlanabileceğine yönelik önemli yönetimsel sonuçların oluşmasına kaynak niteliği taşımaktadır (Schierz, Schilke ve Wirtz, 2010, s. 209). 
Mevcut çalışmanın ana hatları şu şekilde devam etmektedir: İlk olarak, çalışmada kullanılan TAM ile ilgili tanımlamalar yapılmış ve model değişkenleri ayrıntılı olarak ele alınmıştır. Daha sonra TAM ve m-ödeme ile ilgili yapılmış önceki çalışmalar incelenerek analiz sonuçları sunulmuştur (bkz. Tablo 1 ve 2). Yapılan araştırmalar sonucunda araştırma modeli ve hipotezleri oluşturulmuştur. Modeli doğrulamak ve hipotezleri test etmek amacıyla ölçek (literatürden derlenen) geliştirilmiş ve sonrasında kolay örnekleme metodu ile veriler toplanmıştır. Toplanan veriler SPSS ve AMOS programları aracılığıyla değerlendirilmiş ve analiz sonuçları sunulmuştur.

\section{Teorik Çerçeve ve Literatür Taraması}

\subsection{Teknoloji Kabul Modeli}

Bilgi teknolojilerinin bireyler tarafindan kabul edilme nedenlerini tahmin edebilmek ve açıklayabilmek adına Fred D. Davis (1989) yapmış olduğu çalışmasında Teknoloji Kabul Modelini (TAM) ortaya koymuştur. Davis TAM'1, Ajzen ve Fishbein'in (1980) "Sebepli Davranış Teorisinin" bir uzantısı olarak kabul edilmektedir. Teknoloji kullanıcılarının davranışlarını kapsamlı bir şekilde yorumlayabilmek ve teknoloji kabulünün belirleyici değişkenleri için temel/ teorik açıklama yapabilmek TAM'ın temel amacını oluşturmaktadır (Davis, 1989, s. 985). TAM; algılanan kullanım kolaylığı, algılanan fayda, tutum, niyet ve gerçek sistem kullanımı olmak üzere beş temel değişkene sahiptir. Bu değişkenlerin teorik çerçevesi aşağıda açıklanmıştır.

\subsubsection{Algılanan Kullanım Kolaylığ1}

TAM'da yer alan algılanan kullanım kolaylı̆̆ı değişkeni (AKK), bireyin teknolojiyi/ sistemi herhangi bir çaba (zihinsel, fiziksel) sarf etmeden kullanabileceğine inanma derecesi olarak tanımlanmaktadır (Davis, 1989, s. 320). Bir başka ifadeyle AKK, alışverişi nihai sonuca götüren sürece ilişkin tüketici algilarını ifade etmektedir (Monsuwé, Dellaert ve Ruyter, 2004, s.108). Algilanan fayda değişkeninin AKK değişkeninden dolaylı olarak etkilendiği yapılan incelemeler sonucu ortaya çıkmıştır (Davis, 1989, s. 320). Yapılan analizler sonucunda bu görüş desteklenmektedir.

\subsubsection{Alg1lanan Fayda}

Fayda, mal ve hizmetlerin kullanılarak ihtiyaçların direk olarak karşılanması esnasında bireyin duymuş olduğu haz olarak tanımlanmaktadır (TDK, 2019). Literatürde algılanan fayda ile ilgili farklı tanımlamalar yapılmıştır; Davis (1989, s. 320)'a göre algılanan fayda, bireyin herhangi bir sistemi/ teknolojiyi kullanmasının iş performansını artırabileceğine inanma derecesidir. Başka bir tanıma göre algılanan fayda, tüketicilerin alışveriş deneyimi sonucunda oluşan algilarıdır (Monsuwé vd., 2004, s. 108). 


\subsubsection{Tutum}

TAM'ın bir başka değişkeni olan tutum, bir davranışın gerçekleşmesine yönelik olarak, bireyin sergilemiş olduğu duygu (olumlu ya da olumsuz) belirtisidir (Çivici ve Kale, 2007, ss. 120-121). TAM' da algılanan fayda (AF) ve algılanan kullanım kolaylığı (AKK) değişkenleri bireyin tutumunu şekillendiren temel değişkenlerdir (Taylor ve Todd, 1995, s. 561).

\subsubsection{Niyet}

Niyet, bireyin bir davranışı gösterme eğilimidir. TAM'a göre, algılanan kullanım kolaylığı (AKK) ve algılanan fayda (AF) niyet değişkeni ile ilişki içerisindedir (Davis, 1986, s. 16). TRA'ya (TAM'da baz alınan model) göre bireyler genel olarak yapmayı düşündükleri şekilde, mevcut şartlar ve zaman içerisinde davranmaktadır. $\mathrm{Bu}$ nedenle niyet bireyin nihai davranışını belirleyen değişken olarak kabul edilmektedir (Moon ve Kim, 2001, s. 218).

\subsubsection{Gerçek Sistem Kullanımı}

TAM'ın son değişkeni olan gerçek sistem kullanımı, bireyin sistemi/ teknolojiyi hayata geçirip kullanması olarak ifade edilmektedir (Bolat, Aydemir ve Karaman, 2017, s. 67). Son yıllarda gelişen teknoloji ile birlikte Teknoloji Kabul Modeli daha da önemli hale gelmiş ve birçok yazar ve akademisyen tarafından çeşitli araştırma alanlarında test edilerek farklı görüşler ve sonuçlar elde edilmiştir. $\mathrm{Bu}$ görüş ve sonuçlara ilişkin ulusal araştırma sonuçları Tablo 1'de gösterilmiştir.

Tablo 1: TAM ile İlgili Yapılmış Ulusal Araştırma Sonuçları

\begin{tabular}{|c|c|}
\hline $\begin{array}{l}\text { Ustasüleyman } \\
\text { ve } \\
\text { Eyüboğlu } \\
(2010)\end{array}$ & $\begin{array}{l}\text { Çalışmada internet bankacılı̆̆ının kabulünü etkileyen faktörler } \\
\text { TAM'a güven ve algılanan web güvenliği değişkenleri } \\
\text { eklenerek araştırılmıştır. Analizler sonucunda internet } \\
\text { bankacılığına duyulan güven üzerinde algilanan kullanışlılığın } \\
\text { anlamlı etkisi olduğu; güven ve algılanan web güvenliğinin ise } \\
\text { internet bankacılığı kullanım niyetini etkilediği görülmüştür. }\end{array}$ \\
\hline $\begin{array}{l}\text { Özer, Özcan } \\
\text { ve Aktaş } \\
\text { (2010) }\end{array}$ & $\begin{array}{l}\text { Muhasebecilerin bilgi teknolojilerini kullanma sebeplerinin } \\
\text { TAM ile incelendiği bu çalışmada, bilgi teknolojisinin algılanan } \\
\text { kullanım kolaylığı ile algılanan faydasının tutum üzerinde, } \\
\text { tutumun ise bilgi teknolojisini kullanmaya yönelik niyet } \\
\text { üzerinde olumlu yönde etkisinin olduğu ortaya çıkmıştır. }\end{array}$ \\
\hline $\begin{array}{l}\text { Menzi, Önal } \\
\text { ve Çalışkan } \\
\text { (2012) }\end{array}$ & $\begin{array}{l}\text { Bu çalışmada, TAM değişkenleri kapsamında akademisyenlerin } \\
\text { mobil teknolojileri eğitimde kullanılmaya yönelik görüşleri } \\
\text { içerik analizi ile incelenmiştir. Araştırma sonucunda mobil } \\
\text { teknolojilerin kullanımının kolay olması eğitimde bu cihazlar } \\
\text { kullanmaya yönelik tutumu olumlu yönde etkilediği } \\
\text { vurgulanmıştır. }\end{array}$ \\
\hline
\end{tabular}


Tablo 1: TAM ile İlgili Yapılmış Ulusal Araştırma Sonuçları (Devamı)

\begin{tabular}{|c|c|}
\hline $\begin{array}{l}\text { Ceylan, Genç } \\
\text { ve Erem } \\
\text { (2013) }\end{array}$ & $\begin{array}{l}\text { Bu çalışmada, bireysel bankacılık müşterilerinin internet } \\
\text { bankacılığını benimsemelerinde etkili olan faktörler TAM } \\
\text { çerçevesinde incelenmiştir. Analizler sonucunda, müşterilerin } \\
\text { internet bankacıllğına ilişkin algılanan faydası ve algılanan } \\
\text { kullanım kolaylığının, internet bankacılığını kullanmaya yönelik } \\
\text { tutumlarını etkilediği; tutumlarının ise internet bankacılığını } \\
\text { kullanmaya yönelik niyetlerini etkilediği görülmüştür. }\end{array}$ \\
\hline $\begin{array}{l}\text { Tüfekci } \\
\text { (2014) }\end{array}$ & $\begin{array}{l}\text { Üniversite öğrencilerinin karekodların pazarlama iletişiminde } \\
\text { kullanılmasına yönelik görüşlerinin TAM ile test edildiği } \\
\text { çalışmada karekodların yapısal özelliklerinin teknolojiyi } \\
\text { kullanma niyeti üzerinde olumlu etkisi olduğu tespit edilmiştir. }\end{array}$ \\
\hline $\begin{array}{l}\text { Çabuk, Tanrıkulu } \\
\text { Ve Gelibolu } \\
\text { (2014) }\end{array}$ & $\begin{array}{l}\text { İlaç piyasasında faaliyet gösteren satış gücünün teknoloji } \\
\text { kabulüne etki eden faktörler TAM'a kişisel inovasyon değişkeni } \\
\text { eklenerek incelenmiştir. Elde edilen bulgularda, TAM'da yer } \\
\text { alan değişkenlerin etki yönleri teyit edilmekle birlikte, kişisel } \\
\text { inovasyonun da bu değişkenleri etkilediği görülmüştür. }\end{array}$ \\
\hline $\begin{array}{l}\text { Eyüboğlu } \\
\text { ve } \\
\text { Sevim } \\
(2016)\end{array}$ & $\begin{array}{l}\text { Alışverişlerde QR kod kullanımının benimsenmesinde etkili } \\
\text { olan faktörlerin araştırıldığı çalışmada, QR kod uygulamasının } \\
\text { algılanan kullanışl1lığ ile algılanan eğlenebilirliğinin } \\
\text { uygulamayı kullanma niyeti üzerinde etkisi olduğu sonucuna } \\
\text { ulaşılmıştır. }\end{array}$ \\
\hline $\begin{array}{c}\text { Eyüboğlu } \\
\text { ve } \\
\text { Sevim (2017) }\end{array}$ & $\begin{array}{l}\text { Temassız kredi kartı kullanımını etkileyen faktörlerin } \\
\text { araştırıldığı bu çalışmada, temassız özellikli kredi kartlarına } \\
\text { ilişkin algılanan kullanım kolaylığının temassız kart kullanma } \\
\text { niyeti üzerinde doğrudan; algılanan kullanışlılığın ise dolaylı } \\
\text { etkisi olduğu tespit edilmiştir. }\end{array}$ \\
\hline $\begin{array}{l}\text { Kalyoncuoğlu } \\
\text { (2018) }\end{array}$ & $\begin{array}{l}\text { Çevrimiçi alışverişlerde sanal kart kullanımına etki eden } \\
\text { faktörlerin TAM ile incelendiği çalış̧mada TAM'ın alt } \\
\text { değişkenlerinin } 0.61 \text { düzeyinde çevrimiçi alışverişlerde sanal } \\
\text { kart kullanımını açıkladığı ifade edilmiştir. }\end{array}$ \\
\hline $\begin{array}{c}\text { Özer vd. } \\
\text { (2019) }\end{array}$ & $\begin{array}{l}\text { Bu çalışma kullanıcıların e-ödeme araçlarını kullanma ve kabul } \\
\text { etme düzeyleriyle ilgili tahmin ve öngörülerde bulunmak ve } \\
\text { bireylerin bu konudaki tutumlarını ve niyetlerini ortaya koymak } \\
\text { amacıyla yapılmıştı. Yapılan analizler sonucunda AKK, AF, } \\
\text { algılanan risk ve tutum değişkenlerinin e-ödeme araçlarını fiili } \\
\text { olarak kullanma değişkeni üzerinde etkili olmadığı ancak } \\
\text { davranışsal niyetin fiili kullanım üzerinde etkili olduğu } \\
\text { görülmüştür. }\end{array}$ \\
\hline
\end{tabular}

Tablo 1'de özetlenen ulusal araştırmaların yanı sıra uluslararası literatürde de TAM'1 test eden benzer çalışmalar yapılmış ve Tablo 2'de gösterilmiştir. 


\section{Tablo 2: TAM İle İlgili Yapılmış Uluslararası Araştırma Sonuçları}

\begin{tabular}{|c|c|}
\hline $\begin{array}{c}\text { Keil, Beranek } \\
\text { ve Konsynski } \\
\text { (1995) }\end{array}$ & $\begin{array}{l}\text { ilgi sistemlerinin kullanıcılar tarafından kabulünde } \mathrm{AF} \text { ve } \\
\text { KK değişkenlerinin ne ölçütte etkili olduğunun araştırıldığı bu } \\
\text { lışmada, bilgi sistemi kullanımında AF değişkeninin AKK } \\
\text { ğgişkeninden daha önemli/etkili olduğu ortaya çımıştır. }\end{array}$ \\
\hline $\begin{array}{l}\text { Straub, } \\
\text { ve Bren } \\
(1997\end{array}$ & $\begin{array}{l}\text { TAM'ın farklı ülkelerde (İsviçre, ABD ve Japonya) } \\
\text { geçerliliğini test etmek amaciyla üç farklı havayolunun } \\
\text { çalışanları üzerinde yapılan bu çalışmanın sonucunda, İsviçre ve } \\
\text { ABD ülkelerinde TAM'ın geçerli olduğu, Japonya'da ise geçerli } \\
\text { olmadığ görülmüştür. }\end{array}$ \\
\hline $\begin{array}{r}\text { Hu, Cha } \\
\text { ve } \\
(1\end{array}$ & $\begin{array}{l}\text { Bu çalışmada, Hong Kong'daki üçüncü seviye kamu } \\
\text { hastanelerinde çalışan doktorların sağlık hizmeti kapsamında } \\
\text { Teletıp teknolojisini kabul etmelerine etki eden faktörler } \\
\text { incelenmiştir. İnceleme sonucunda elde edilen veriler, AF'nin } \\
\text { tutum ve niyet değişkenlerinin önemli bir belirleyicisi olduğunu } \\
\text { ortaya çıkarırken; AKK'nin niyet ve tutumun bir belirleyicisi } \\
\text { olmadı̆ğını göstermiştir. }\end{array}$ \\
\hline $\begin{array}{l}\text { Chau } \\
\text { ve } \\
\text { Lai } \\
(2003)\end{array}$ & $\begin{array}{l}\text { Çalışmada, internet bankacılığının kabulüne etki eden faktörler } \\
\text { araştırılmışı. Araştırma sonucunda kullanıcıları internet } \\
\text { bankacıllı̆ını kabul etmelerinde en etkili değişkenin AKK } \\
\text { olduğu tespit edilirken; kişiselleştirme ve erişilebilirlik } \\
\text { yapılarının ise AF ve AKK üzerinde önemli bir etkiye sahip } \\
\text { olduğu ve bu durumun da internet bankacılığ kabulüne yönelik } \\
\text { tutumun gelişmesinde önemli bir değişken olarak rol aldığ1 } \\
\text { sonucuna ulaşılmıştır. }\end{array}$ \\
\hline Zmije & $\begin{array}{l}\text { Yazarlar; AKK, kullanışlılık, mobilite, maliyet, güven ve } \\
\text { anlamlılık olmak üzere bir dizi faktörün her birinin, m-ödeme } \\
\text { uygulamalarını benimseme üzerinde etkiye sahip olduğu } \\
\text { varsayımını TAM'1 genişleterek test etmiştir. Çalışma ile m- } \\
\text { ödeme kabul modelini iyileştirilmek ve doğrulamak } \\
\text { amaçlanmaktadır. }\end{array}$ \\
\hline $\begin{array}{l}\text { Pikkarainen, } \\
\text { Pikkarainen, } \\
\text { Karjaluoto ve } \\
\text { Pahnila } \\
\quad(2004)\end{array}$ & $\begin{array}{l}\text { Bu çalışma, Finlandiya' daki özel banka müşterilerinin çevrimiçi } \\
\text { bankacıllı̆ benimseme nedenlerini gün yüzüne çıarmak } \\
\text { amacıyla yapılmıştır. Araştırmanın kavramsal boyutunda } \\
\text { TAM'dan yararlanılmış ve web sitesinin algılanan faydasının } \\
\text { çevrimiçi bankacılığın benimsenmesinde temel faktör olduğu } \\
\text { sonucuna ulaşılmıştır. }\end{array}$ \\
\hline
\end{tabular}


Tablo 2: TAM İle İlgili Yapılmış Uluslararası Araştırma Sonuçları (Devamı)

\begin{tabular}{|c|c|}
\hline $\begin{array}{l}\text { Lee, Cheung } \\
\text { ve Chen } \\
\text { (2005) }\end{array}$ & $\begin{array}{l}\text { Üniversite ögrencilerinin internet tabanlı öğrenmeyi kabul etme } \\
\text { nedenlerinin araştırıldığ çalışmada, ögrencilerin uygulamaya } \\
\text { yönelik algılanan faydasının internet tabanlı öğrenmeyi } \\
\text { kullanma niyetini etkilediği ancak algılanan kullanım } \\
\text { kolaylığının niyet üzerinde önemli bir etkisinin olmadığı tespit } \\
\text { edilmiştir. }\end{array}$ \\
\hline $\begin{array}{c}\text { Sipior, } \\
\text { Ward ve } \\
\text { Connolly } \\
(2011)\end{array}$ & $\begin{array}{l}\text { ABD'de yaşayan kişilerin e-devlet hizmetlerini kullanmalarında } \\
\text { etkili olan faktörlerin araştırıldığ bu çalışmadan elde edilen } \\
\text { bulgularda, algılanan faydanın e-devlet hizmetlerini kullanma } \\
\text { üzerinde etkisinin olmadığ ancak algılanan kullanım } \\
\text { kolaylığının e-hizmet kullanımı üzerinde önemli ölçüde etkili } \\
\text { olduğu görülmüştür. }\end{array}$ \\
\hline $\begin{array}{c}\text { Cho ve } \\
\text { Sagynov } \\
(2015)\end{array}$ & $\begin{array}{l}\text { Bu çalışmada, tüketicilerin internet üzerinden alışveriş yapma } \\
\text { davranışlarına etki eden faktörler araştırılmıştır. Araştırma } \\
\text { sonuçları, güven, AF ve AKK faktörlerinin tüketicilerin } \\
\text { internetten alışveriş yapma niyeti üzerinde anlamlı bir etkiye } \\
\text { sahip olduğunu göstermiştir. }\end{array}$ \\
\hline $\begin{array}{c}\text { Ohk, Park } \\
\text { ve Hong } \\
(2015)\end{array}$ & $\begin{array}{l}\text { Bu çalışmada, AF, AKK ve TAM'a eklenen yeni değişkenlerin } \\
\text { (navigasyon kolaylığı, etkileşim) mobil uygulama memnuniyeti } \\
\text { üzerindeki etkileri araştırılmıştır. Yapılan analizler ile AF, AKK } \\
\text { ve etkileşim algısının tüketici memnuniyetini olumlu yönde } \\
\text { etkilediği; memnuniyetin ise mobil uygulamayı kullanma } \\
\text { niyetini olumlu yönde etkilediği sonucuna varılmıştır. }\end{array}$ \\
\hline $\begin{array}{l}\text { Baabdullah, } \\
\text { Nasseef ve } \\
\text { Alalwan } \\
(2016)\end{array}$ & $\begin{array}{l}\text { Suudi Arabistan'daki mobil devlet hizmetlerini kullanma } \\
\text { niyetini artırabilecek faktörlerin araştırıldığ çalışmada, } \\
\text { tüketicilerin mobil hükümet hizmetlerini kullanma konusunda } \\
\text { güçlü bir niyete sahip oldukları ve bu hizmetin AKK'nin } \\
\text { kişilerin hizmete ilişkin AF'sını önemli ölçüde etkilediği tespit } \\
\text { edilmiştir. }\end{array}$ \\
\hline $\begin{array}{c}\text { Elkaseh, Wong ve } \\
\text { Fung } \\
\text { (2016) }\end{array}$ & $\begin{array}{l}\text { Libya yükseköğretimindeki öğrencilerin ve öğretmenlerin e- } \\
\text { öğrenmeyi kabul etme ve kullanma niyetlerini etkileyen } \\
\text { faktörlerin araştırıldığı çalışmada, AF'nin ve AKK'nin e- } \\
\text { öğrenmeyi kabul etme ve kullanma niyeti üzerinde etkili kilit } \\
\text { faktörler olduğu ortaya çıkarılmıştır. }\end{array}$ \\
\hline $\begin{array}{l}\text { Raza, Umer } \\
\text { ve Shah } \\
\text { (2017) }\end{array}$ & $\begin{array}{l}\text { Bu çalışmada, Pakistan'da mobil bankacılığı kullanma niyetine } \\
\text { etki eden değişkenler incelenmiştir. İnceleme sonucunda, mobil } \\
\text { bankacılığın AKK'nin kullanıcının AF's1 ve tutumu ile AF'nin } \\
\text { ise tutum ve niyet ile anlamlı bir ilişki içerisinde olduğu tespit } \\
\text { edilmiştir. Ayrıca tutumun, mobil bankacılık kullanma niyeti ile } \\
\text { pozitif yönde bağlantılı olduğu sonucuna ulaşılmıştır. }\end{array}$ \\
\hline
\end{tabular}


Tablo 2: TAM İle İlgili Yapılmış Uluslararası Araştırma Sonuçları (Devamı)

\begin{tabular}{|c|c|}
\hline $\begin{array}{l}\text { Zhang, Lu } \\
\text { ve Kizidag } \\
\text { (2018) }\end{array}$ & $\begin{array}{l}\text { Tüketicilerin mobil bankacılık hizmetlerini kullanmalarına etki } \\
\text { eden faktörleri belirlemek amaciyla yapılmış olan bu çalışmanın } \\
\text { kavramsal boyutunda TAM kullanılmıştır. Yapılan analizler } \\
\text { sonucunda algılanan fayda ve algılanan kullanım kolaylığının } \\
\text { tüketicilerin mobil bankacılığı kabul etmesinde etkili olduğu ve } \\
\text { mobil teknoloji üzerindeki güvenirlilik ve gizlilik faktörlerinin } \\
\text { tüketiciler üzerinde büyük bir rol üstlendiği görülmüştür. }\end{array}$ \\
\hline $\begin{array}{l}\text { Doshi } \\
\text { (2018) }\end{array}$ & $\begin{array}{l}\text { E-ticaret sitesi kullanımına etki eden faktörlerin araştırıldığ } \\
\text { çalışmada, AKK ve AF değişkenlerinin e-ticaret sitesi } \\
\text { teknolojilerinin tüketiciler tarafından kabulünde önemli bir rol } \\
\text { oynadığı sonucuna ulaşılmıştır. }\end{array}$ \\
\hline Askool vd. (2019) & $\begin{array}{l}\text { Mobil ödeme kabulünü teknik (teknoloji özellikleri), biçimsel } \\
\text { (örgütsel öncüller) ve gayri resmi (uyumluluk, algılanan risk ve } \\
\text { kişisel yenilikçilik) olmak üzere üç düzeyde değerlendiren } \\
\text { yazarlar, bu düzeylerin m-ödemeyi kullanma ve benimseme } \\
\text { niyetini etkileyebilecek anahtar değişkenler olduğunu } \\
\text { öngörmektedir. }\end{array}$ \\
\hline $\begin{array}{l}\text { Malaquias } \\
\text { ve } \\
\text { Hwang } \\
(2019)\end{array}$ & $\begin{array}{l}\text { Brezilya ve ABD örnekleminde mobil bankacılık kullanımına } \\
\text { etki eden faktörleri keşfetmek amacıyla yapılan çalışmada, } \\
\text { algılanan kullanım kolaylığı ve güven parametrelerinin her iki } \\
\text { ülke örnekleminde mobil bankacılığın algılanan faydasına etki } \\
\text { ettiği görülmüştür. }\end{array}$ \\
\hline $\begin{array}{l}\text { Hu, Ding, Li, Chen } \\
\text { ve Yang } \\
\text { (2019) }\end{array}$ & $\begin{array}{l}\text { Çin Kırsal Ticaret Bankası müşterilerinin Fintech hizmetlerini } \\
\text { benimseme nedenlerinin araştırıldığ çalışmada, Fintech } \\
\text { hizmetlerine olan güvenin kullanıcının tutumu üzerinde olumlu } \\
\text { etkisinin olduğu ancak algılanan kullanım kolaylığının ve } \\
\text { algılanan riskin kullanıcı tutumu üzerinde etkisinin olmadığ } \\
\text { sonucuna ulaşılmıştır. }\end{array}$ \\
\hline $\begin{array}{l}\text { Li, Wang, } \\
\text { Wangh ve } \\
\text { Zhou } \\
(2019)\end{array}$ & $\begin{array}{l}\text { Genişletilmiş TAM ile Çin örnekleminde kullanıcının Alipay’1 } \\
\text { (ödeme sistemi) benimsemesine etki eden faktörlerin } \\
\text { araştırıldığ çalışmada, algılanan kullanışlılığın ve algılanan } \\
\text { kullanım kolaylığının kullanıcıların Alipay'1 kullanma } \\
\text { konusundaki niyetleri ve tutumları üzerinde olumlu etkisinin } \\
\text { olduğu ancak risk algısının, algılanan kullanım kolaylığı ve } \\
\text { algılanan kullanışl1lı üzerinde olumsuz etkisinin olduğu ortaya } \\
\text { çıkmıştır. }\end{array}$ \\
\hline
\end{tabular}

\section{Araştırma Modeli ve Hipotezler}

Araştırmanın modeli (Şekil 1), bireylerin teknoloji kabulünü etkileyen faktörleri temel alan Teknoloji Kabul Modeli (TAM) (Davis, 1989) doğrultusunda oluşturulmuştur. TAM, özellikle bankacılık sektöründe mobil destekli uygulamaları teorik olarak desteklemek amacıyla literatürde sıklıkla kullanılmaktadır (Pedersen ve Nysveen, 2003; James, Pirim, Boswell, Reithel ve 
Barkhi, 2006; Ha, Yoon ve Choi 2007; Chen, 2008; Tassabehji ve Kamala, 2009; Schierz vd., 2010; Wessels ve Drennan, 2010).

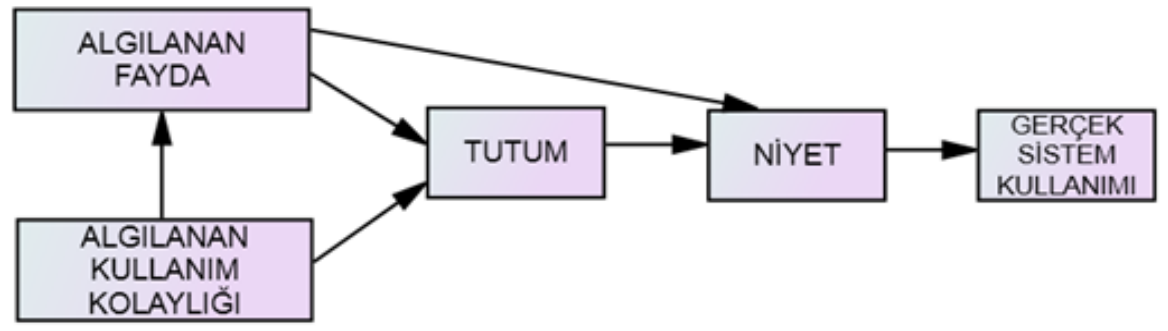

\section{Şekil 1: Araştırma Modeli}

TAM, teknoloji kullanımını tahmin etmek ve/veya açıklamak için birtakım öneriler sunmaktadır. Modelde, sistem kullanımının temel belirleyicilerinin algılanan fayda ve algılanan kullanım kolaylığı olduğu görülmektedir (Davis, 1989, s. 320). Modele göre gerçek sistem kullanımını, algılanan kullanım kolaylığı ve algılanan fayda tarafından şekillenen tutumun dolaylı etkilediği niyet belirlemektedir.

Araştırma amacına ve literatüre dayanan aşağıdaki hipotezler test edilecektir:

H1:Tüketicinin m-ödeme işlemine ilişkin algılanan kullanım kolaylığının, algılanan faydası üzerinde doğrudan pozitif yönde etkisi vardır.

H2:Tüketicinin m-ödeme işlemine ilişkin algılanan kullanım kolaylı̆̆ının, mödemeyi kullanmaya yönelik tutumu üzerinde doğrudan pozitif yönde etkisi vardir.

H3:Tüketicinin m-ödeme işlemine ilişkin algılanan faydasının, m-ödemeyi kullanmaya yönelik tutumu üzerinde doğrudan pozitif yönde etkisi vardır.

H4:Tüketicinin m-ödeme işlemine ilişkin algılanan kullanım kolaylığının, mödemeyi kullanmaya yönelik niyeti üzerinde dolaylı pozitif yönde etkisi vardır.

H5:Tüketicinin m-ödeme işlemine ilişkin algılanan faydasının, m-ödemeyi kullanma niyeti üzerinde doğrudan pozitif yönde etkisi vardır.

H6:Tüketicinin m-ödeme işlemine ilişkin tutumunun, m-ödemeyi kullanma niyeti üzerinde doğrudan pozitif yönde etkisi vardır.

H7:Tüketicinin m-ödeme işlemine ilişkin algılanan kullanım kolaylığının, mödeme işlemini gerçekte kullanma davranışı üzerinde dolaylı pozitif yönde etkisi vardir.

H8:Tüketicinin m-ödeme işlemine ilişkin algılanan faydasının, m-ödeme işlemini gerçekte kullanma davranışı üzerinde dolaylı pozitif yönde etkisi vardır.

H9:Tüketicinin m-ödeme işlemine ilişkin tutumunun, m-ödeme işlemini gerçekte kullanma davranışı üzerinde dolaylı pozitif yönde etkisi vardır.

H10:Tüketicinin m-ödeme işlemine ilişkin kullanma niyetinin, m-ödeme işlemini gerçekte kullanma davranışı üzerinde doğrudan pozitif yönde etkisi vardır. 


\section{Araştırma Metodolojisi}

\section{1.Ölçeğin Geliştirilmesi}

Araştırma modeli doğrultusunda tasarlanan ölçeği oluştururken daha önce geçerliği ve güvenirliği test edilmiş ölçekler kullanılmıştır. Algılanan kullanım kolaylığı ve algılanan fayda yapılarına ilişkin ifadeler Davis (1986, ss. 254255)'in orijinal ölçeğinden alınmıştır. Tutum yapısına ilişkin ifadeler Agarwal, Ahuja, Carter ve Gans (1998, s. 18)'den alınmıştır. Niyet yapısına ilişkin ifadeler Moon ve Kim (2001, s. 228)'den; gerçek sistem kullanımına ilişkin ifadeler ise Igbaria, Zinatelli, Cragg ve Cavaye (1997, s. 303)'den alınmıştır. Ölçeğe dahil edilen toplamda 29 ifade mobil ödemeyle ilişkili olacak şekilde revize edilmiştir. Tam sayılı uygulamaya geçilmeden önce beşli Likert tipi ifadelerin anlaşılırlığını, geçerliğini ve güvenirliğini test etmek amaciyla çoğunluğun akademisyenlerden (m-ödemeyi daha önce kullanan) oluştuğu 80 kişilik bir örneklem üzerinde pilot araştırma yapılmıştır. Pilot araştırmada 29 ifadeli ölçeğin Cronbach's $\alpha$ değeri 0.83 bulunmuştur. Açıklayıcı faktör analizi sonucunda algılanan kullanım kolaylığı yapısı altında yer alan ve faktör yükü 0.30 'un altında kalan iki ifade (mobil ödeme sistemi etkileşim için katı ve esnek değildir- mobil ödeme kullanma konusunda ustalaşmak için çaba sarf ediyorum) tam sayılı uygulama anketinden çıkarılmıştır. Çıkarılan ifadeler sonrası ölçeğin açıklanan toplam varyansı 54.771; modelde yer alan AKK, AF, Tutum, Niyet ve Gerçek Sistem Kullanımı (GSK) yapılarına ilişkin güvenirlik değerleri ise sırasıyla $0.72-0.87-0.83-0.80-0.83$ olarak bulunmuştur. İfadelere ilişkin faktör yükleri ise 0.583-0.954 aralığında değer almıştır. Ön analizler ve katılımcı yorumlamaları sonucunda 27 ifadeli anket formu üzerinden nihai analizler yapılmıştır.

\section{2. Örneklem ve Veri Toplama}

Araştırmanın ana kütlesini, Nevşehir ilinde ikamet eden ve mobil ödeme teknolojisini en az bir kez kullanan yaşları 18 ve üzeri tüketiciler oluşturmaktadır. Ana kütleyi oluşturan tüketicilerin tamamına ulaşmak mümkün olmadığından örneklemeye gidilmiş ve kolayda örnekleme yöntemi tercih edilmiştir. Veriler toplanırken yüz yüze anket tekniği kullanılmıştır. Veri toplama işlemi yaklaşık beş hafta sürmüştür. Süre sonunda 520 adet anket toplanmış ancak kullanılabilir 500 anket analizlere dahil edilmiştir. Marsh, Balla ve Mcdolanld (1988)'e göre maksimum olabilirlik metodu tercih edilerek yapılan faktör analizlerinde örneklem büyüklüğünün en az 100 veya değişken sayısının 10 katı olması gerekmektedir. $\mathrm{Bu}$ bağlamda araştırma örnekleminin yeterli sayıda olduğu söylenebilmektedir. Örneklemin temsil gücünü artırmak için farklı cinsiyet, yaş, gelir ve eğitim düzeyinde tüketiciler örneğe seçilmiş ve ayrıntılar Tablo 3 'te gösterilmiştir. 
Tablo 3: Katılımcılara İlişkin Tanımlayıcı İstatistikler

\begin{tabular}{|c|c|c|c|c|c|}
\hline Cinsiyet & n & $\%$ & Yaş & $\mathbf{n}$ & $\%$ \\
\hline Kadın & 197 & 39 & 18-25 Yaş & 39 & 8 \\
\hline Erkek & 303 & 61 & 26-35 Yaş & 130 & 26 \\
\hline Toplam & 500 & 100 & $36-45$ Yaş & 157 & 31 \\
\hline & & & 46-55 Yaş & 136 & 27 \\
\hline Gelir Düzeyi & $\mathbf{n}$ & $\%$ & 55 ve üzeri & 38 & 8 \\
\hline $2.000-2.499 \mathrm{TL}$ & 80 & 16 & Toplam & 500 & 100 \\
\hline 2.500-3.499 TL & 111 & 22 & & & \\
\hline 3.500-4.499 TL & 134 & 27 & Ĕgitim Düzeyi & $\mathbf{n}$ & $\%$ \\
\hline $4.500-5.499 \mathrm{TL}$ & 131 & 26 & İlköğretim & 11 & 3 \\
\hline $5.500 \mathrm{TL}$ ve üzeri & 44 & 9 & Lise & 161 & 32 \\
\hline Toplam & 500 & 100 & Ön Lisans & 89 & 18 \\
\hline & & & Lisans & 187 & 37 \\
\hline Meslek & $\mathbf{n}$ & $\%$ & Lisansüstü & 52 & 10 \\
\hline Kamu Çalışanı & 89 & 18 & Toplam & 500 & 100 \\
\hline Özel Sektör & 159 & 32 & & & \\
\hline Emekli & 20 & 4 & M-Ödeme Kullanım Alanı & $\mathbf{n}$ & $\%$ \\
\hline Öğrenci & 12 & 3 & Alışveriş Merkezleri & 74 & 15 \\
\hline Ev Hanımı & 7 & 1 & Marketler/Mağazalar & 100 & 20 \\
\hline Serbest Meslek & 79 & 15 & Akaryakıt İstasyonları & 132 & 26 \\
\hline Diğer & 134 & 27 & E-ticaret Portalları & 123 & 25 \\
\hline Toplam & 500 & 100 & Fatura Ödeme Merkezleri & 71 & 14 \\
\hline & & & Toplam & 500 & 100 \\
\hline \multicolumn{4}{|c|}{ Hangi bankanın m-ödeme sistemini kullanıyorsunuz? } & $\mathbf{n}$ & $\%$ \\
\hline \multicolumn{4}{|l|}{ Denizbank } & 77 & 15 \\
\hline \multicolumn{4}{|l|}{ Yapı Kredi Bankası } & 83 & 17 \\
\hline \multicolumn{4}{|l|}{ Garanti Bankası } & 72 & 14 \\
\hline \multicolumn{4}{|l|}{ İş Bankası } & 102 & 21 \\
\hline \multicolumn{4}{|l|}{ Diğer } & 166 & 33 \\
\hline \multicolumn{4}{|l|}{ Toplam } & 500 & 100 \\
\hline
\end{tabular}

Tablo 3 incelendiğinde araştırmaya katılanların \%39'unun kadın, \%61'inin erkek olduğu görülmektedir. Katılımcıların \%31'i 26-35 yaş aralığındadır. Katılımcıların \%37'si lisans düzeyinde eğitime sahiptir. Ek olarak \%32'lik bir oranla katılımcıların çoğunluğu özel sektör çalışanıdır. Katılımcılar çoğunlukla akaryakıt istasyonlarında ve e-ticaret portallarında mobil ödeme sistemlerini kullanmaktadır. Banka tercihine bakıldığında \%21'lik bir oranla İş Bankası sıralamanın başında yer almaktadır. 


\section{Veri Analizi}

Ölçekte yer alan çok sayıda gözlenebilir değişkeni daha az sayıda ilgili gizil değişken altında toplamak (Yap ve Khong, 2006, s. 593) amacıyla SPSS paket programı aracılığıyla Açıklayıcı Faktör Analizi (AFA) yapılmışı̧ı. Analize ilişkin sonuçlar Tablo 4’te gösterilmiştir.

Tablo 4: Açıklayıcı Faktör Analizi Sonuçları

\begin{tabular}{|c|c|c|c|}
\hline KMO & \multicolumn{3}{|c|}{0.950} \\
\hline Bartlett's & \multicolumn{3}{|c|}{0.000} \\
\hline$\chi^{2}$ & \multicolumn{3}{|c|}{7943.472} \\
\hline Top.Varyans & \multicolumn{3}{|c|}{67.623} \\
\hline Rotasyon & \multicolumn{3}{|c|}{11} \\
\hline Faktör Yük Aralığı & \multicolumn{3}{|c|}{$0.70-0.96$} \\
\hline & $\boldsymbol{\alpha}$ & $\begin{array}{c}\text { Öz } \\
\text { Değer }\end{array}$ & $\begin{array}{c}\text { Varyans } \\
(\%)\end{array}$ \\
\hline $\mathbf{A F}$ & 0.91 & 11.221 & 32.799 \\
\hline AKK & 0.93 & 3.598 & 20.282 \\
\hline TUTUM & 0.87 & 2.160 & 5,574 \\
\hline NIYET & 0.83 & 1.914 & 6.512 \\
\hline GSK & 0.89 & 1.659 & 2.455 \\
\hline Toplam $\alpha^{*}$ & 0.95 & & \\
\hline $\begin{array}{l}\text { Not: } A F=\text { Algılanan Fayda, } A \\
\text { GSK }=\text { Gerçek Sistem Kullanı } \\
\alpha \text { değeridir. }\end{array}$ & Algilan & $\begin{array}{l}\text { kullanım } \\
\text { sin topla }\end{array}$ & $\begin{array}{l}\text { laylığ } 1, \\
\text { Cronbach }\end{array}$ \\
\hline
\end{tabular}

Yapılan AFA sonucunda KMO değeri 0.950, Bartlett's testi anlamlığ ise 0.000 bulunmuştur. $\mathrm{Bu}$ değerler verilerin faktör analizi yapmaya uygun olduğunu göstermektedir (Dziuban ve Shirkey, 1974 s. 359). Maksimum olabilirlik (maximum likelihood) ve oblimin tekniği kullanılarak yapılan analizin devamında faktör yükleri 0.70 'in, öz değerleri 1'in üzerinde olan (Hair, William, Babin ve Anderson 2006, s. 391) ve toplam varyansın \%67.623'ünü açıklayan 5 faktör ve 21 ifade elde edilmiştir. Faktör yükü 0.70'nin altında olan AF faktöründen iki, AKK faktöründen üç, niyet faktöründen bir ifade analiz dışı tutulmuştur.

\section{1. Ölçüm Modelinin Analizi}

Ölçüm modelini doğrulamak amacıyla Anderson ve Gerbing (1988)'in öne sürdüğü iki aşamalı yaklaşımı kullanılmıştır. İlk aşamada AFA sonucunda ortaya çıkan faktörlerin literatürde daha önce yapılan çalışma sonuçları ile benzer bir yapıda olup olmadığını (Meydan ve Şeşen, 2015, s. 57) test etmek amaciyla AMOS 23 paket programı aracılığıyla Doğrulayıcı Faktör Analizi (DFA) yapılmıştır. DFA'daki gizil ve gözlenebilir değişkenler, AFA sonucu ortaya çıkan 5 faktör 21 ifadeden oluşturulmuştur. Araştırmanın örnek hacmi $(n=500)$ ve cevaplayıcıların gözlenebilir değişkenlere oranı $(500: 21=24)$ DFA için uygun bir 
nitelik taşımaktadır (Hair vd., 2006, s.604). Analizde AF, AKK, tutum, niyet ve GSK gizil değişkenleri altında sırasıyla 8, 5, 4, 2, 2 gözlenebilir değişken kullanılmıştır. Modelin iyim uygunluğu değerlerini artırmak amacıyla AKK gizil değişkeni altındaki AKK1 ve AKK10 gözlenebilir değişkenlerine ait hata terimleri (e9-e13) arasında kovaryans oluşturulmuştur. Analizin ikinci aşamasında ise araştırma hipotezlerini test etmek amacıyla yol (path) analizi yapılmıştır. $\mathrm{Bu}$ analize ilişkin sonuçlara Tablo 7'de yer verilmiştir.

\section{2. Ölçüm Modelinin Değerlendirilmesi}

Ölçüm modeli, Schermelleh-Engel, Moosbrugger ve Müller (2003, s.52)'nin literatüre kazandırdığı altı (X2/sd, NFI, GFI, CFI, AGFI ve RMSEA) iyim uygunluğu kriteri ile değerlendirilmiştir. Değerlendirmeye ilişkin kabul edilebilir uyum aralıkları Tablo 5'te gösterilmiştir.

Tablo 5: Kabul Edilebilir Uyum Aralıkları

\begin{tabular}{cc}
\hline $\mathrm{X}^{2} / \mathrm{sd}$ & $2<\mathrm{X}^{2} / \mathrm{sd} \leq 3$ \\
$\mathrm{NFI}$ & $0.90 \leq \mathrm{NFI}<0.95$ \\
$\mathrm{GFI}$ & $0.90 \leq \mathrm{GFI}<0.95$ \\
$\mathrm{CFI}$ & $0.95 \leq \mathrm{CFI}<0.97$ \\
AGFI & $0.85 \leq \mathrm{AGFI}<0.90$ \\
RMSEA & $0.05<\mathrm{RMSEA} \leq 0.08$ \\
\hline Kaynak: Schermelleh-Engel vd., 2003, s. 52
\end{tabular}

Tablo 5'te görüldüğü gibi ölçüm modeline ilişkin iyim uygunluğu kriterleri kabul edilebilir uyum aralığında bulunmuştur $(\mathrm{X} 2 / \mathrm{sd}=2.705, \mathrm{NFI}=0.940$, $\mathrm{GFI}=0.916, \mathrm{CFI}=0.961, \mathrm{AGFI}=0.891$ ve $\mathrm{RMSEA}=0.058)$. üst sinır olarak kabul edilen 0.08 değerinin (Browne ve Cudeck, 1992; Byrne, 2001) altında bir değer almıştır. NFI değerinin 0-1 arasında bir değer alması iyi ve kabul edilebilir uyum olarak değerlendirilir. 0.90'1 aşan NFI değerleri kabul edilebilir bir uyum göstermektedir (Bentler ve Bonnet, 1980). GFI değerinin ise alt sınır olan 0.90 değerine yakın olduğu söylenebilir. Analizin bir sonraki adımda ölçüm modelinin yap1 güvenirliği ve geçerliliği kontrol edilmiştir.

\subsubsection{Yap1 Güvenirliği (Birleşik Güvenirlik-CR)}

Yap1 güvenirliğini sınamak için Cronbach's $\alpha$ katsayısı hesaplanarak incelenmiştir. Modelde yer alan AF ( 8 ifade), AKK (5 ifade), Tutum (4 ifade), Niyet ( 2 ifade) ve GSK ( 2 ifade) yapılara ilişkin birleşik güvenirlik katsayıları sirasiyla $0.91-0.93$ - 0.87 - 0.83 ve 0.89 olarak bulunmuştur. George ve Mallery (2016, s. 240)'a göre $\alpha>0.90$ ise ölçülen yapı mükemmel, $\alpha>0.80$ ise iyi derecede 
güvenirliğe sahiptir. Bu bağlamda AF ve AKK yapıları "mükemmel"; tutum, niyet ve GSK yapıları ise "iyi” derecede güvenilirdir.

\subsubsection{Yap1 Geçerliği}

Ölçüm modelinin yapı geçerliğini test etmek amacıyla yakınsak ve ayırıcı geçerlik yaklaşımlarından yararlanılmıştır. Yakınsak geçerlik, gizil değişkeni oluşturan gözlenebilir değişkenlerin ne derece ilişkili olduğunu göstermektedir (Park, 2009, s. 155). Yakınsak geçerlik doğrulanırken yapılara ilişkin birleşik güvenirlik değerlerinin 0.70'den, AVE (Açıklanan Ortalama Varyans) değerlerinin ise 0.50'den büyük olması beklenmektedir (Hair vd., 2006, s. 656). Tablo 6'ya bakıldığında birleşik güvenirlik değerlerinin 0.83'ün, AVE değerlerinin ise 0.50'nin üzerinde olduğu görülmektedir. $\mathrm{Bu}$ doğrultuda ölçüm modelinin yakınsak geçerliğe sahip olduğu söylenebilir

Tablo 6: Ölçüm Modeline İlişkin Güvenirlik, Geçerlik ve Korelâsyon Katsayıları

\begin{tabular}{lcccccc}
\hline & AVE & AF & AKK & TUTUM & NIYET & GSK \\
\hline AF & 0.57 & $(0.91)$ & & & & \\
AKK & 0.67 & $0.50^{*}$ & $(0.93)$ & & & \\
TUTUM & 0.70 & $0.69^{*}$ & $0.52^{*}$ & $(0.87)$ & & \\
NiYET & 0.76 & $0.55^{*}$ & $0.49^{*}$ & $0.71^{*}$ & $(0.83)$ & \\
GSK & 0.79 & $0.38^{*}$ & $0.34^{*}$ & $0.44^{*}$ & $0.36^{*}$ & $(0.89)$ \\
\hline
\end{tabular}

Not: AF=Algılanan Fayda, AKK=Algılanan Kullanım Kolaylığı, GSK=Gerçek Sistem Kullanımı. AVE=Faktör yüklerinin karelerinin ortalaması. ${ }^{*}$ Faktörler arası korelâsyonun karesi. Parantez içindeki rakamlar birleşik güvenirlikleri göstermektedir.

Ayırıcı geçerlik ise, modeldeki yapılar arasındaki korelasyonlar incelenerek doğrulanmıştır. Ölçüm modelinin ayırıcı geçerliğe sahip olması için korelasyon katsayılarının 0.85 'ten küçük olması gerekmektedir (Park, 2009, s. 155). Bir başka yaklaşıma göre AVE değerlerinin, model yapıları arasındaki korelasyonun karesinden büyük olması, ölçüm modelinin ayırıcı geçerliğe sahip olduğunu göstermektedir (Fornell ve Larcker, 1981, s. 41). Bu çalışmada Fornell ve Larcker'in yaklaşımı kullanılmış ve Tablo 6'da yapılar arasındaki korelasyonun karesi değerlerine yer verilmiştir. Sonuç olarak ölçüm modelinin ayırıcı geçerliğinin olduğunu görülmektedir.

\subsection{Araştırma Hipotezlerinin Testi}

Analizin son aşamasında ölçüm modelindeki yapılar arasındaki ilişkilerin (yolların) gücünü, yönünü ve anlamlı olup olmadığını test etmek (Meydan ve Şeşen, 2015, s. 97) amacıyla path (yol) analizi yapılmıştır. Analiz sonuçlarına ilişkin AMOS diyagramı Şekil 2'de gösterilmektedir. 


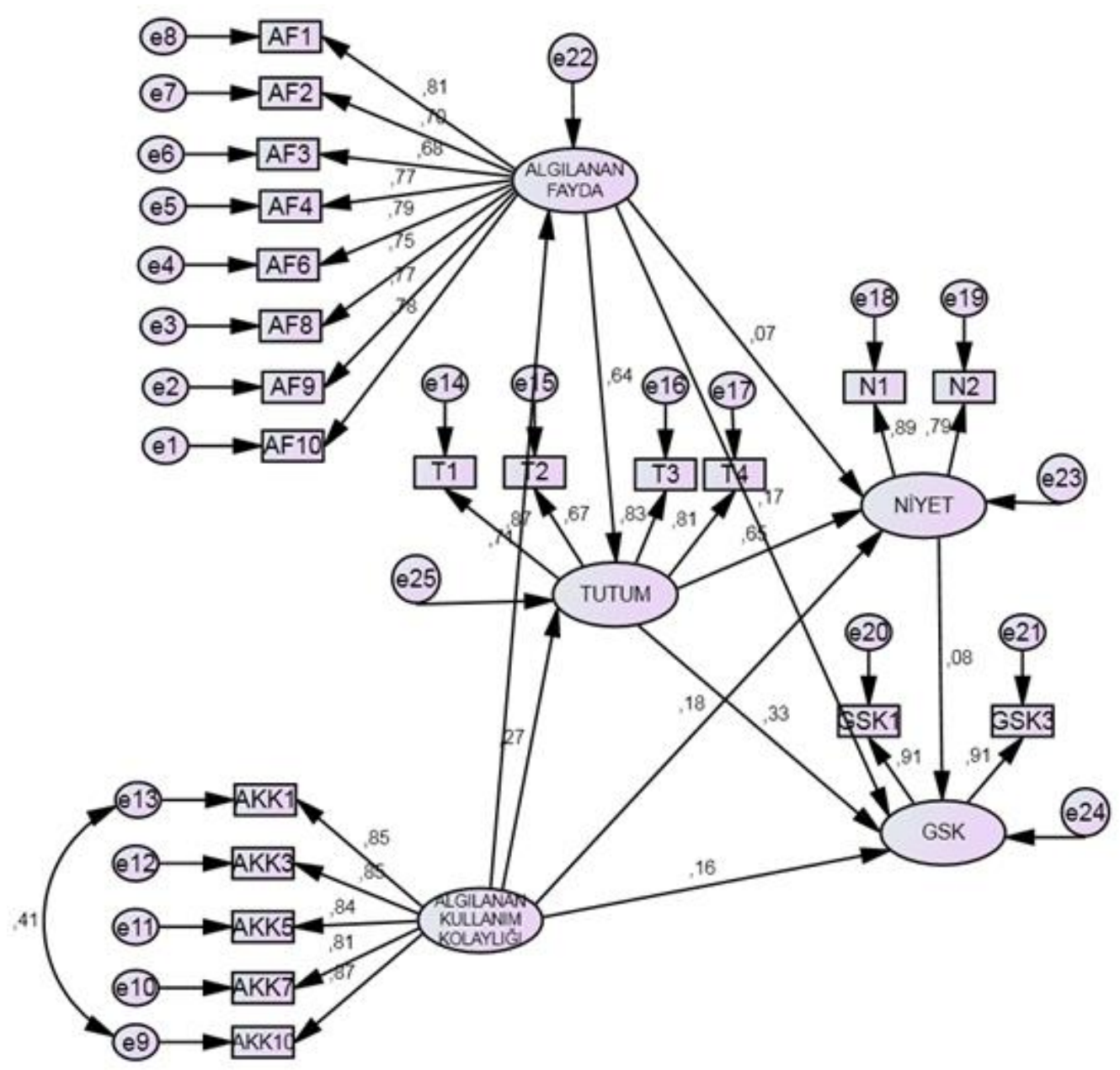

Şekil 2: Path (Yol) Analizi Diyagramı

Şekil 2'de verilen analiz sonuçları, algılanan kullanım kolaylığı ile algılanan fayda arasinda (0.71); algilanan fayda ile tutum arasinda (0.64); tutum ve niyet arasında (0.65) ayrı ayrı doğrudan pozitif yönlü ilişki olduğunu doğrulamaktadır $(\mathrm{p}<0.01)$. Algılanan kullanım kolaylığ ile tutum arasında 0.27 oranla doğrudan, 0.46 oranla dolaylı pozitif yönlü ilişki vardır $(\mathrm{p}<.01)$. Algılanan kullanım kolaylığı ile niyet arasında (0.52); algılanan kullanım kolaylığı ile gerçek sistem kullanımı arasında (0.42) ve algılanan fayda ile gerçek sistem kullanımı arasında $(0.25)$ ayrı ayrı dolaylı pozitif yönlü ilişki vardır $(\mathrm{p}<.05)$. Ayrıca tutum ile gerçek sistem kullanımı arasında (0.33) doğrudan pozitif yönlü ilişki bulunmuştur $(\mathrm{p}<.05)$. Ancak algilanan fayda ve niyet arasında; niyet ile gerçek sistem kullanımı arasında doğrudan pozitif yönlü ve anlamlı bir ilişki bulunamamışırır. Bu bağlamda H1, H2, H3, H4 H6, H7 ve H8 hipotezleri kabul edilmiş; H5 ve H10 hipotezleri reddedilmiştir. Tablo 7, yapısal modelin hipotez testi sonuçlarını göstermektedir. 
Tablo 7: Parametre Tahminleri, t Değeri ve Hipotez Sonuçları

\begin{tabular}{|c|c|c|c|c|c|}
\hline \multirow[b]{2}{*}{ Hipotez Yolu } & \multicolumn{4}{|c|}{ Standardize Edilmiş Tahminler } & \multirow[b]{2}{*}{$\begin{array}{l}\text { Hipotez } \\
\text { Sonuçları }\end{array}$} \\
\hline & $\begin{array}{l}\text { Doğrudan } \\
\text { Etki }\end{array}$ & $\begin{array}{c}\mathrm{t} \\
\text { Değeri }\end{array}$ & $\begin{array}{l}\text { Dolayl1 } \\
\text { Etki }\end{array}$ & $\begin{array}{l}\text { Toplam } \\
\text { Etki }\end{array}$ & \\
\hline $\mathrm{AKK} \rightarrow \mathrm{AF}\left(\mathrm{H}_{1}\right)$ & 0.71 & 14.90 & - & 0.71 & Kabul $^{*}$ \\
\hline $\mathrm{AKK} \rightarrow \mathrm{TUTUM}\left(\mathrm{H}_{2}\right)$ & 0.27 & 5.52 & 0.46 & 0.73 & Kabul* $^{*}$ \\
\hline $\mathrm{AF} \rightarrow \mathrm{TUTUM}\left(\mathrm{H}_{3}\right)$ & 0.64 & 11.77 & - & 0.64 & Kabul $^{*}$ \\
\hline $\mathrm{AKK} \rightarrow \mathrm{NIYET}\left(\mathrm{H}_{4}\right)$ & 0.18 & 3.17 & 0.52 & 0.70 & Kabul $^{* *}$ \\
\hline $\mathrm{AF} \rightarrow \mathrm{NIYET}\left(\mathrm{H}_{5}\right)$ & 0.07 & 0.92 & 0.42 & 0.49 & Ret \\
\hline TUTUM $\rightarrow$ NIYET $\left(\mathrm{H}_{6}\right)$ & 0.65 & 8.02 & - & 0.65 & Kabul* $^{*}$ \\
\hline $\mathrm{AKK} \rightarrow \mathrm{GSK}\left(\mathrm{H}_{7}\right)$ & 0.16 & 2.49 & 0.42 & 0.58 & Kabul $^{* *}$ \\
\hline $\mathrm{AF} \rightarrow \mathrm{GSK}\left(\mathrm{H}_{8}\right)$ & 0.18 & 2.09 & 0.25 & 0.43 & $\mathrm{Kabul}^{* *}$ \\
\hline TUTUM $\rightarrow$ GSK $\left(\mathrm{H}_{9}\right)$ & 0.33 & 2.87 & 0.05 & 0.38 & Kabul $^{* *}$ \\
\hline $\mathrm{NIYET} \rightarrow \mathrm{GSK}\left(\mathrm{H}_{10}\right)$ & 0.08 & 0.89 & - & 0.08 & Ret \\
\hline Uyum İndeksi & \multicolumn{5}{|c|}{ Model İyim Uygunluğu Değerleri } \\
\hline $\mathrm{X}^{2} / \mathrm{sd}$ & \multicolumn{5}{|c|}{2.705} \\
\hline NFI & \multicolumn{5}{|c|}{0.940} \\
\hline GFI & \multicolumn{5}{|c|}{0.916} \\
\hline CFI & \multicolumn{5}{|c|}{0.961} \\
\hline AGFI & \multicolumn{5}{|c|}{0.891} \\
\hline RMSEA & \multicolumn{5}{|c|}{0.058} \\
\hline
\end{tabular}

Not: $A F=A l g l$ lanan Fayda, AKK=Algılanan Kullanım Kolaylığı, GSK=Gerçek Sistem Kullanımı. $*<0.01$ anlamlılık düzeyinde kabul $* *<0.05$ anlamlılık düzeyinde kabul.

Algılanan fayda kullanıcı tutumunu önemli düzeyde (0.64) etkilemektedir. Buna karşılık algılanan kullanım kolaylığının tutum üzerindeki doğrudan etkisi, algılanan fayda aracılığıyla olan (dolaylı) etkisinden çok daha azdır. Gerçek sistem kullanımını doğrudan etkileyen en önemli değişken tutum iken dolaylı olarak etkileyen en önemli değişken ise algılanan kullanım kolaylığıdır.

\section{Sonuç}

$\mathrm{Bu}$ çalışmada m-ödeme teknolojisi kabulünü etkileyen faktörleri açıklayan bir araştırma modeli önerilmektedir. Orijinal TAM'a dayanan araştırma modeli anket uygulaması ile test edilmiştir. Literatürde daha önce yapılmış çalışmalarla benzer bir şekilde araştırma sonuçları, TAM'ın m-ödeme teknolojisini kullanma davranışını açıklamaya yardımcı olan teorik bir model olduğunu doğrulamıştır (Moon ve Kim, 2001; Yang ve Yoo, 2004; Chen, 2008; Park, 2009). Araştırma sonuçları mobil ödeme teknoloji kullanım kabulünün "algılanan fayda", "algılanan kullanım kolaylığı" ve "tutum" olmak üzere üç temel faktör tarafindan belirlendiğini göstermiştir. Algılanan kullanım kolaylığı ve algılanan fayda tarafindan şekillenen tüketici tutumu, Suh ve Han (2002)'ın çalışmasıyla benzer bir şekilde mobil ödeme teknoloji kabulünde önemli etkiye (0.33) sahip faktör 
olarak bulunmuştur. Kotler (2000, s. 175)'e göre tutum, tüketicinin bir nesneye veya fikre (mobil ödeme teknolojisi) yönelik olumlu veya olumsuz değerlendirmeleridir ve tüketicinin fikirlerinin davranışa dönüşmesinde önemli etkiye sahip bir belirleyicidir. $\mathrm{Bu}$ bağlamda tüketici tutumunu olumlu açıdan şekillendiren yapıcı uygulamaların mobil ödeme sistemine entegre edilmesi işletmelere avantaj sağlayacaktır. $\mathrm{Bu}$ araştırma mobil ödeme teknolojisini kullanan işletmelere tüketici bakış açısıyla teknoloji kabulünü etkileyen faktörlerin bir çıktısını sunmaktadır.

Önerilen modelde öncelikle algılanan kullanım kolaylığının algılanan fayda üzerinde 0.71 oranında doğrudan pozitif yönde etkisi olduğu bulunmuştur. $\mathrm{Bu}$ sonuç literatürde daha önce yapılmış araştırma sonuçlarını doğrulamaktadır (Shih, 2004; Lee, Cheung ve Chen, 2005; Chen, 2008; Kim, Mirusmonov ve Lee, 2009 ve Park, 2009). Bu bağlamda mobil ödeme sisteminin net, anlaşılır ve kolay olmasının tüketicinin m-ödeme sisteminden algıladığı faydayı pozitif yönde etkilediği bu durumun ise gerçek sistem kullanımı üzerinde olumlu tutum yarattığ söylenebilir. Ancak Lee vd. (2005)'nin çalışmalarında olduğu gibi bu çalışmada da tüketicinin mobil ödeme sistemine ilişkin algıladığı kullanım kolaylığının tüketici tutumunu doğrudan güçlü bir şekilde etkilediğini söylemek doğru olmayacaktır. Sonuçlar, mobil ödeme sistem kullanımının net, anlaşılır ve kolay olmasının, tüketicinin işlemlerini yaparken ki verimliliğini, etkinliğini, hızını ya da genel olarak işlem kalitesini artırdığı sürece tüketici tutumu üzerinde dolaylı bir etkiye (algılanan fayda aracılığıyla 0.46) sahip olacağını göstermektedir. Ayrıca bu bulgu, iyi tasarlanmış ve kullanımı kolay bir teknolojik uygulamanın, yararlı olarak algılanmadığı takdirde kullanılamayacağı görüşüne sahip olan önceki araştırmaları desteklemektedir (Chau ve Lai, 2003; Eriksson, Kerem ve Nilsson, 2005). Doğrudan etki bakımından karşılaştırıldığında Shih (2004)'in eticaretin kabulü üzerine yaptığı ampirik çalışması ile benzer bir şekilde algılanan faydanın tutum üzerindeki doğrudan etkisi (0.64) algılanan kullanım kolaylığına (0.27) göre çok daha yüksektir. Bu durum m-ödeme teknolojisinin kabulünde iyi tasarlanmış sistem altyapısının önemini ortaya koymaktadır. Modelin sonraki adımında algılanan fayda ve algılanan kullanım kolaylığının gerçekte mobil ödeme sistem kullanımına (GSK) doğrudan etki düzeyleri (sırasıyla 0.18-0.16) tutumun aracı etkisinden dolayı düşmektedir. Araştırma sonuçları dolaylı etki düzeyleri açısından incelendiğinde önceki çalışmalarla benzer bir şekilde algılanan kullanım kolaylığının tüketicilerin m-ödeme teknolojisini kullanmayı kabul etmelerinde en önemli ve belirleyici (0.42) bir değişken olduğu görülmektedir (Chau ve Lai, 2003).

Yukarıdaki araştırma sonuçları önceki araştırma sonuçları ile paralellik taşırken bir kısım sonuçlar ise önceki çalışmalara aykırı nitelik taşımaktadır. Orijinal TAM, algılanan faydanın niyet üzerinde doğrudan etkisi olduğunu savunurken bu araştırmada Park (2009)'ın çalışması ile benzer bir şekilde algılanan faydanın niyet üzerinde doğrudan bir etkisi bulunamamıştır. Bu bulgu, algılanan faydanın 
niyet üzerinde doğrudan bir etkisi olduğunu tespit eden Lee vd. (2005) ve Raza vd. (2017)'nin çalışmalarına aykırı nitelik taşımaktadır. Daha öncede ifade edildiği üzere algılanan fayda tutumu, tutum da niyeti (0.65) etkilemektedir. Bu bağlamda algılanan faydanın niyet üzerinde doğrudan bir etkisi olmamasına rağmen tutum aracı değişkeni üzerinde 0.42 oranında dolaylı etkiye sahip olduğu görülmektedir (Shih, 2004). Bu duruma ek olarak tüketicilerin mobil ödeme sistemini kullanma niyetleri fiili olarak mobil ödemeyi kullanma davranışını doğrudan etkilememektedir. Tutumun gerçek sistem kullanımı üzerinde tek başına etkili olmaması, niyetin aracı etkisini gündeme getirmekte ve tutumun niyeti etkilediği niyetin de gerçek sistem kullanımı davranışını şekillendirdiği düşünülmektedir (Vallerand, Deshaies, Cuerrieri Pelletier ve Mongeau, 1992; Szajna, 1996). Araştırma sonucunda niyetin gerçek sistem kullanımı üzerinde etkili olmaması, katılımcıların m-ödeme sistemini gelecekte kullanmaya yönelik görüşlerini, m-ödeme teknolojisine sahip uygulamaların kullanımının başlangıç aşamasında olduğundan dolayı fiili olarak davranışlarına yansıtamadıkları ile açıklanabilir. $\mathrm{Bu}$ bağlamda gelecek araştırmalarda aynı veya farklı örneklem üzerinde teknoloji kullanımı öncesi yaşanan belirsizliği ve zararları ifade eden algılanan risk faktörü (Chen ve He, 2003, s.680) TAM'a eklenerek model yeniden test edilebilir.

\subsection{Kisitlar}

$\mathrm{Bu}$ çalışmada araştırma modelinin sınamak için m-ödeme teknolojisi kullanıcılarına anket uygulaması yapılmıştır. Tüketicilerin yenilikçi ödeme teknolojilerine yatkınlığının artması ve bu konudaki yükselen trend nedeniyle uygulama alanı olarak m-ödeme teknolojisi seçilmiştir. Nevşehir ilinde gerçekleştirilen bu çalışmadaki en temel kısıt, m-ödeme teknolojisini kullanan tüketicilerin net sayısına tam olarak ulaşılamamasıdır. Bu nedenle çalışmada, örneklem büyüklüğünü nicel olarak belirleyen tabakalı örnekleme metodu gibi yöntemler kullanılamamıştır. Örneklemin temsil gücünü artırmak için mümkün olduğunca çok kullanıcı ile anket uygulaması yapılmıştır. Anket uygulamasının ilk koşulunun 'm-ödeme teknolojisini en az bir kez kullanmak' olması, araştırmanın bir diğer kısıtını oluşturmaktadır. Bu durum örneğe seçilecek kişi sayısını sınırlamaktadır. Ayrıca çalışmanın sonuçları Nevşehir iline özgüdür. Sonuçların Türkiye bağlamında genelleştirilebilmesi için Türkiye ana kütlesinde örneklem belirleyerek çalışma tekrarlanmalıdır. 


\section{Kaynaklar}

Agarwal, R., Ahuja, M., Carter, P. E. \& Gans, M. (1998). Early and late adopters of IT innovations: Extensions to innovation diffusion theory. In Proceedings of the DIGIT Conference, 1-18.

Anderson, J. C. \& Gerbing, D. W. (1988). Structural equation modeling in practice: A review and recommended two-step approach. Psychological Bulletin, 103 (3), 411-423. https://doi.org/10.1037/0033-2909.103.3.411

Askool, S., Pan, Y. C., Jacobs, A. \& Tan, C. (2019). Understanding proximity mobile payment adoption through technology acceptance model and organisational semiotics: An exploratory study. In 24th UK Academy for Information Systems International Conference, Oxford, UK, 9-10 April 2019.

Baabdullah, A., Nasseef, O. \& Alalwan, A. (2016). Consumer adoption of mobile government in the Kingdom of Saudi Arabia: The role of usefulness, ease of use, perceived risk and innovativeness. Social Media: The Good, the Bad, and the Ugly, 267-279. https://doi.org/10.1007 / 978-3-319-45234-0_25

Bentler, P. M. \& Bonnet, D. G. (1980). Significance tests and goodness-of-fit in the analysis of covariance structure. Psychological Bulletin, 88 (3), 588-606. https://doi.org/10.1037/0033-2909.88.3.588

Bolat, Y. İ., Aydemir, M. ve Karaman, S. (2017). Uzaktan eğitim öğrencilerinin öğretimsel etkinliklerde mobil internet kullanımlarının teknoloji kabul modeline göre incelenmesi. Gazi Eğitim Fakültesi Dergisi, 37 (1), 63-91.

Browne, M. W. \& Cudeck, R. (1992). Alternative ways of assessing model fit. Sociological Methods \& Research, 21 (2), 230-258. https://doi.org/10.1177/0049124192021002005

Byrne, B. M. (2001). Structural equation modeling, with AMOS: Basic concepts, applications and programming. Mahwah, New Jersey: Lawrence Erlbaum Associates.

Ceylan, H. H., Genç, E. ve Erem, I. (2013). Tüketicilerin internet bankacılığını benimsemesini etkileyen faktörlerin yapısal eşitlik modeli ile araştırılması. Anadolu Üniversitesi Sosyal Bilimler Dergisi,13 (3), 143-154.

Chau, P. Y. \& Lai, V. S. (2003). An empirical investigation of the determinants of user acceptance of internet banking. Journal of Organizational Computing and Electronic Commerce, 13(2), 123-145. https://doi.org/10.1207/S15327744JOCE1302_3 
Chen, L. D. (2008). A model of consumer acceptance of mobile payment. International Journal of Mobile Communications, 6 (1), 32-52. https://doi.org/10.1504 / IJMC.2008.015997

Chen, R. \& He, F. (2003). Examination of brand knowledge, perceived risk and consumers' intention to adopt an online retailer. Tom \& Business Excellence, 40 (6), 677-693. https://doi.org/10.1080/1478336032000053825

Cho, Y. C. \& Sagynov, E. (2015). Exploring factors that affect usefulness, ease of use, trust, and purchase intention in the online environment. International Journal of Management \& Information Systems, 19 (1), 21-36. https://doi.org/10.19030/ijmis.v19i1.9086

Çabuk, S., Tanrıkulu, C. ve Gelibolu, L. (2014). Satışçıların teknoloji kabulü ve kişisel yenilikçiliğin teknoloji kabulüne etkisi. Cumhuriyet Üniversitesi İktisadi ve İdari Bilimler Dergisi, 15 (1), 397-420.

Çivici, T. ve Kale, S. (2007). Mimari tasarım bürolarında bilişim teknolojilerinin kullanımını etkileyen faktörler: Bir yapısal denklem modeli. 4. Inşaat Yönetimi Kongresi, 119-128.

Dahlberg, T., Mallat, N., Ondrus, J. \& Zmijewska, A. (2006). Mobile payment market and research - past, present and future. Working Papers on Information Systems, 6 (48), 1-16.

Dahlberg, T., Mallat, N., Ondrus, J. \& Zmijewska, A. (2007). Past, present and future of mobile payments research: A literature review. Electronic Commerce Research and Applications, 1-17. https://doi.org/10.1016/j.elerap.2007.02.001

Davis, F. D. (1986). A technology acceptance model for empirically testing new enduser information system: Theory and results. Doctoral Dissertation, Sloan School of Management, Massachusetts Institute of Technology.

Davis, F. D. (1989). Perceived usefulness perceived ease of use, and user acceptance of information technology. MIS Quarterly, 13 (3), 319-340. https://doi.org/10.2307/249008

Doshi, P. V. (2018). Relationship of perceived ease use and perceived usefulness on usage of e-commerce site. International Journal of Academic Research and Development, 3 (1), 495-498.

Dziuban, C. D., \& Shirkey, E. C. (1974). When is a correlation matrix appropriate for factor analysis? Some decision rules. Psychological Bulletin, 81 (6), 358-361. https://doi.org/10.1037/h0036316 
Elkaseh, A. M., Wong, K. W. \& Fung C. C. (2016). Perceived ease of use and perceived usefulness of social media for e-learning in libyan higher education: A structural equation modeling analysis. International Journal of Information and Education Technology, 6 (3), 192-199. https://doi.org/10.7763/IJIET.2016.V6.683

Eriksson, K., Kerem, K. \& Nilsson, D. (2005). Customer acceptance of internet banking in estonia. International Journal of Bank Marketing, 23 (2), 200216. https://doi.org/10.1108/02652320510584412

Eyüboğlu, K. ve Sevim U. (2016). Determinants of consumers' adoption to shopping with QR code in Turkey. The Journal of International Social Research, 9 (43), 1830-1839.

Eyüboğlu, K. ve Sevim, U. (2017). Determinants of contactless credit cards acceptance in Turkey. Uluslararası Yönetim İktisat ve Issletme Dergisi, 13 (2), 311-330. http://dx.doi.org/10.17130/ijmeb.2017228687

Fornell C. \& Larcker, D. F. (1981). Evaluating structural equation models with unobservable variables and measurement error. Journal of Marketing Research, 18 (1), 39-50. https://doi.org/10.2307/3151312

George, D. \& Mallery, P. (2016). SPSS for Windows step by step: A simple guide and reference (14th ed.). New York: Routledge Taylor \& Francis.

Ha, I., Yoon, Y. \& Choi, M. (2007). Determinants of adoption of mobile games under mobile broadband wireless access environment. Information \& Management, 44 (3), 276-286. https://doi.org/10.1016/ j.im.2007.01.001

Hair, J. F., Black, W. C., Babin, B. J. \& Anderson, R. E. (2006). Multivariate data analysis (Seventh Edition). New Jersey: Pearson Prentice Hall.

Hu, P. J., Chau, P.Y.K., Shheng, O. R L. \& Tam, K. Y. (1999). Examining the technology acceptance model using physician acceptance of telemedicine technology. Journal of Management Information Systems, 16 (2), 91-112. https://doi.org/10.1080/07421222.1999.11518247

Hu, Z., Ding, S., Li, S., Chen, L. \& Yang, S. (2019). Adoption intention of FinTech services for bank users: An empirical examination with an extended Technology Acceptance Model. Symmetry, 11 (3), 1-16. https://doi.org/10.3390/sym11030340

Igbaria, M., Zinatelli, N., Cragg, P. \& Cavaye, A. L. (1997). Personal computing acceptance factors in small firms: A structural equation model. MIS Quarterly, 21 (3), 279-305. https://doi.org/10.2307/249498 
İşbankası, (2012). İş Bankası'ndan Ödeme Sistemlerinde Devrim Yaratacak Uygulama: Parakod. https://www.isbank.com.tr/TR/hakkimizda/haberlerve-medya/haberler/, Erişim Tarihi: 28.08.2019.

James, T., Pirim, T., Boswell, K., Reithel, B. \& Barkhi, R. (2006). Determining the intention to use biometric devices: An application and extension of the technology acceptance model. Journal of Organizational and End User Computing, 18 (3), 1-24. https://doi.org/10.4018/joeuc.2006070101

Kalyoncuoğlu, S. (2018). Tüketicilerin online alışverişlerindeki sanal kart kullanımlarının teknoloji kabul modeli ile incelenmesi. Afyon Kocatepe Üniversitesi Sosyal Bilimler Dergisi, 20 (2), 193-213.

Keil, M., Beranek, P. M. \& Konsynski, B. R. (1995). Usefulness and ease of use: field study evidence regarding task considerations. Decision Support Systems, 13, 75-91. https://doi.org/10.1016/0167-9236(94)e0032-m

Kim, C., Mirusmonov, M. \& Lee, I. (2009). An empirical examination of factors influencing the intention to use mobile payment. Computers in Human Behavior, 26 (3), 310-322. https://doi.org/10.1016/j.chb.2009.10.013

Kotler, P. (2000). Pazarlama yönetimi. Nejat Muallimoğlu (Çev.). İstanbul: Beta Basım A.Ş.

Kutsal, S. (2018). Dünden Bugüne Dijital Ödeme Sistemlerinin Evrimi. https://digitalage.com.tr/dunden-bugune-dijital-odeme-sistemlerinin-evrimi/, Erişim Tarihi: 28.08.2019.

Lee, M. K. O., Cheung, C. M. K. \& Chen, Z. (2005). Acceptance of Internetbased learning medium: The role of extrinsic and intrinsic motivation. Information \& Management, 42 (8), 1095-1104. https://doi.org/10.1016/j.im.2003.10.007

Li, J., Wang, J., Wangh, S. \& Zhou, Y. (2019). Mobile payment with Alipay: An application of extended technology acceptance model. IEEE Acces, 7, 50380-50387. https://doi.org/10.1109/ACCESS.2019.2902905

Malaquias, R. F. \& Hwang, Y. (2019). Mobile banking use: A comparative study with Brazilian and U. S. participants. International Journal of Information Management, 44, 132- 140. https://doi.org/10.1016/j.ijinfomgt.2018.10.004

Mallat, N. (2007). Exploring consumer adoption of mobile payments - a qualitative study. The Journal of Strategic Information Systems, 16 (4), 114. https://doi.org/10.1016/j.jsis.2007.08.001 
Marsh, H. W., Balla, J. R. \& Mcdonald, R. P. (1988). Goodness-of-fit indexes in confirmatory factor analysis: The effect of sample size. Psychological Bulletin, 103 (3), 391-410. https://doi.org/10.1037/0033-2909.103.3.391

Menzi, N., Önal, N. ve Çalışkan, E. (2012). Mobil teknolojilerin eğitim amaçlı kullanımına yönelik akademisyen görüşlerinin teknoloji kabul modeli çerçevesinde incelenmesi. Ege Eğitim Dergisi, 3 (1), 40- 55.

Meydan, C. H. ve Şeşen. H. (2015). Yapısal eşitlik modellemesi Amos uygulamaları (2. Bask1). Ankara: Detay Yayınc1lık.

Monsuwé, T. P., Dellaert, B. G. C. \& Ruyter, K. (2004). What drives consumers to shop online? A literature review. International Journal of Service Industry Management, $15 \quad$ (1), 102-121. https://doi.org/10.1108/09564230410523358

Moon, J. W. \& Kim, Y. G. (2001). Extending the TAM for a world-wide-web context. Information \& Management, 38 (4), 217-230. https://doi.org/10.1016/S0378-7206(00)00061-6

Ohk, K., Park, S. B. \& Hong, J. W. (2015). The influence of perceived usefulness, perceived ease of use, interactivity, and ease of navigation on satisfaction in mobile application. Advanced Science and Technology Letters, 84, 88-92. https://doi.org/10.14257 / astl.2015.84.18

Özer, A. C., Poyraz, E. ve Kızgın, Y. (2019). Nakitsiz toplum yaratmada elektronik ödeme araçlarının benimsenmesi. Business \& Management Studies: An International Journal, 7 (2), 735-755. http://dx.doi.org/10.15295/bmij.v7i2.1032

Özer, G., Özcan, M. ve Aktaş, S. (2010). Muhasebecilerin bilgi teknolojisi kullanımının teknoloji kabul modeli (TKM) ile incelenmesi. Journal of Yasar University, 1, 3278-3293.

Park, S. Y. (2009). An analysis of the technology acceptance model in understanding university students' behavioral intention to use e-learning. Educational Technology \& Society, 12 (3), 150-162.

Pedersen, P. E. \& Nysveen, H. (2003). Usefulness and self-expressiveness: Extending TAM to explain the adoption of a mobile parking service. 16th Bled e-Commerce Conference, 705-717.

Pikkarainen, T., Pikkarainen, K., Karjaluoto, H. \& Pahnila, S. (2004). Consumer acceptance of online banking: An extension of the technology acceptance model. Internet Research, 14 (3), 224-235. https://doi.org/10.1108/10662240410542652 
Raza, S. A., Umer, A. \& Shah, N. (2017). New determinants of ease of use and perceived usefulness for mobile banking adoption. Int. J. Electronic Customer Relationship Management, 11 (1), 44-65. https://doi.org/10.1504/IJECRM.2017.086751

Schermelleh- Engel, K., Moosbrugger, H. \& Müller, H. (2003). Evaluating the fit of structural equation models: Tests of significance and descriptive goodness-of-fit measures. Methods of Psychological Research Online, 8 (2), 23-74.

Schierz, P. G., Schilke, O. \& Wirtz, B. W. (2010). Understanding consumer acceptance of mobile payment services: An empirical analysis. Electronic Commerce Research and Applications, 9 (3), 209-216. https://doi.org/10.1016/j.elerap.2009.07.005

Shih, H. P. (2004). An empirical study on predicting user acceptance of eshopping on the web. Information \& Management, 41, 351-368. https://doi.org/10.1016/S0378-7206(03)00079-X

Sipior, J. C., Ward, B. T. \& Connolly, R. (2011). The digital divide and tgovernment in the united states: Using the technology acceptance model to understand usage. European Journal of Information Systems, 20 (3), 308- 328. https://doi.org/10.1057/ejis.2010.64

Straub, D., Keil, M. \& Brenner, W. (1997). Testing the technology acceptance model across cultures: A three country study. Information \& Management, 33 (1), 1-11. https://doi.org/10.1016/S0378-7206(97)00026-8

Suh, B. \& Han, I. (2002). Effect of trust on customer acceptance of internet banking. Electronic Commerce Research and Applications, 1 (3-4), 247263. https://doi.org/10.1016/S1567-4223(02)00017-0

Szajna, B. (1996). Empirical evaluation of the revised technology acceptance model. Management $\quad$ Science, $42 \quad$ (1), 85-92. https://doi.org/10.1287/mnsc.42.1.85

Tassabehji, R. \& Kamala, M. A. (2009). Improving e-banking security with biometrics: Modelling user attitudes and acceptance. In 2009 3rd International Conference on New Technologies, Mobility and Security, 1-6. https://doi.org/10.1109/NTMS.2009.5384806

Taylor, S. \& Todd, P. (1995). Assessing IT usage: The role of prior experience. MIS Quarterly, 19 (4), 561-570. https://doi.org/10.2307/249633 
TDK, (2019). Büyük Türkçe Sözlük. http://www.tdk.gov.tr/, Erişim Tarihi: 29.08.2019.

Tüfekci, Ö. K. (2014). Karekodların pazarlama iletişimi rolünü teknoloji kabul modeli ile açılamaya yönelik bir araştırma. Pamukkale İşletme ve Bilişim Yönetimi Dergisi, (1), 36-52. https://doi.org/10.5505/pibyd.2014.65375

Ustasüleyman, T. ve Eyüboğlu, K. (2010). Bireylerin internet bankacılığını benimsemesini etkileyen faktörlerin yapısal eşitlik modeli ile belirlenmesi. BDDK Bankacılık ve Finansal Piyasalar, 4 (2), 11-38.

Vallerand, R. J., Deshaies, P., Cuerrier, J., Pelletier, L. G. \& Mongeau, C. (1992). Ajzen and Fishbein's theory of reasoned action as applied to moral behavior: A cofirmatory analysis. Journal of Personality and Social Psychology, 62 (1), 98-109. https://doi.org/10.1037/0022-3514.62.1.98

Wessels, L. \& Drennan, J. (2010). An investigation of consumer acceptance of mbanking. International Journal of Bank Marketing, 28 (7), 547-568. https://doi.org/10,1108/02652321011085194

Yang, H. D. \& Yoo, Y. (2004). It's all about attitude: revisiting the technology acceptance model. Decision Support Systems, 38 (1), 19-31. https://doi.org/10.1016/S0167-9236(03)00062-9

Yap, B. W. \& Khong, K. W. (2006). Examining the effects of customer service management (CSM) on perceived business performance via structural equation modelling. Applied Stochastic Models in Business and Industry, 22 (5-6), 587-605. https://doi.org/10.1002/asmb.648

Zhang, T., Lu, C. \& Kizildag, M. (2018). Banking “on- the- go": Examining consumers' adoption of mobile banking services. International Journal of Quality and Service Sciences, $10 \quad$ (3), 279-295. https://doi.org/10,1108/IJQSS-07-2017-0067

Zmijewska, A., Lawrence, E. \& Steele, R. (2004). Towards understanding of factors influencing user Acceptance of Mobile Payment Systems. IADIS International Conference WWW/Internet 2004, Madrid, Spain, (2), 270-277. 


\section{Investigation of Mobile Payment Technology Acceptance with Technology Acceptance Model: An Empirical Research}

\section{Extended Abstract}

\section{Introduction}

Technological development and related innovative practices created opportunities in the banking sector as well as in many other sectors. Mobile payment technology is one of the innovative banking applications that provides the consumer with convenience and flexibility in their shopping. This application, which enables money transfer without place, time and person restrictions and is becoming more and more widespread, is among the alternative distribution channels of banks.

The aim of this study is to determine the factors affecting consumers in the process of accepting mobile payment technology. In the study, m-payment technology consumer acceptance process is analyzed within the scope of Technology Acceptance Model. In national and international literature, TAM is frequently studied in science, health and social sciences in order to understand the technology acceptance process of the individual. The basis of the studies is based on the doctoral thesis of Fred D. Davis (1986). After Davis (1989) examined the user acceptance of information technologies, Venkadesh and Davis (2000) developed TAM theoretically. The perceived ease of use and perceived usefulness variables in the model has a significant effect on shaping the individual's acceptance of technology. Chen (2008), Moon and Kim (2001), Suh and Han (2002)'s research results confirm this phenomenon. These and similar studies contribute to the theory and practice by making sense of users' adoption of technological applications. In this study, it is questioned whether perceived ease of use, perceived usefulness, attitude and intention, which are the main variables of TAM, directly or indirectly affect the use of m-payment technology.

\section{Methodology}

In the study, one of the primary data collection techniques, questionnaire method was used. The questionnaire was developed by Davis (1986), Agarwal et al. (1998), Moon and Kim (2001: 228) and Igbaria et al. (1997) and five-point Likert technique was used. The main population of the study consists of users who live in Nevsehir city center and who benefit from m-payment technology at least once. The study was conducted between July and August 2019. Face-to-face interviews were conducted in line with the convenience sampling method and 500 questionnaires were collected. The collected data were analyzed through SPSS and AMOS programs. Firstly, explanatory and confirmatory factor analysis was performed on the data and then path analysis was performed to test the hypotheses. As a result of the analyzes, the explained total variance of the five-factor scale was 67,623 ; reliability values of that in the model perceived ease of use, perceived usefulness, attitude and intention and actual system usage structures were found to be respectively $0.93-0.91-0.87-0.83-0.89$. As a result of the confirmatory factor analysis, the model was found to have acceptable fit (Schermelleh-Engel vd., 2003, s. 52). In addition, the results showed that the scale has convergent and discriminant validity.

\section{Results}

Path analysis was carried out with the help of AMOS program to test the 10 hypotheses created within the scope of the research. As a result of the analysis, it was seen that the model's good fit values were within the acceptable fit range $(\mathrm{X} 2 / \mathrm{sd}=2.705, \mathrm{NFI}=0.940, \mathrm{GFI}=0.916, \mathrm{CFI}=0.961$, 
AGFI $=0.891$ ve RMSEA=0.058) (Schermelleh-Engel vd., 2003, s. 52). As a result of the study, perceived usefulness of consumer's perceived ease of use towards m-payment technology; attitude of perceived usefulness; attitude has a direct effect on intention. In addition, perceived ease of use, perceived usefulness and attitudes have an indirect effect on consumers' actual use of m-payment technology. In this context, it can be said that a well-designed and easy-to-use technological application increases the efficiency, efficiency, speed or overall process quality of the consumer and this positively affects the acceptance of the technology.

\section{Conclusion}

Similar to previous studies in the literature, research results have confirmed that TAM is a theoretical model that helps explain the behavior of using m-payment technology (Moon \& Kim, 2001; Yang \& Yoo, 2004; Chen, 2008; Park, 2009). The results of the research showed that the acceptance of mobile payment technology usage is determined by three basic factors: "perceived usefulness ", "perceived ease of use" and "attitude". Consumer attitude, shaped by perceived ease of use and perceived usefulness, has been found to be an important factor in mobile payment technology acceptance (Suh \& Han, 2002). In this context, integrating the constructive applications that shape the consumer attitude positively will provide an advantage to the businesses.

In the study, it was concluded that the perceived ease of use related to the mobile payment system indirectly affected the consumer attitude through the perceived usefulness variable. The direct effect of perceived usefulness on attitude is much higher than perceived ease of use. This supports the view that a well-designed and easy-to-use technological application cannot be used unless it is perceived as useful (Chau \& Lai, 2003; Eriksson, Kerem \& Nilsson, 2005).

Contrary to original TAM and similar studies (Lee et al., 2005; Raza et al., 2017), perceived usefulness could not have a direct effect on intention (Park, 2009). However, perceived usefulness indirectly affects intention through the attitude variable (Shih, 2004). In addition, consumers' intention to use the mobile payment system does not directly affect the behavior of using mobile payments. Attitude is not effective on actual system usage. Attitude is thought to affect actual system use behavior through the variable of intention (Vallerand, Deshaies, Cuerrieri Pelletier \& Mongeau, 1992; Szajna, 1996). The failure of the participants to reflect their behavior at their views on using the m-payment system in the future can be explained by the fact that the applications using the m-payment technology are at the beginning level. In this context, the model can be retested by adding to TAM the perceived risk factor (Chen \& He, 2003, p. 680) that expresses the uncertainty and losses experienced before the use of technology on the same or different sample in future studies. 